\title{
Correction in CRPC CUA Guideline
}

Cite as: Can Urol Assoc J 2015;9(11-12):E925-6. http://dx.doi.org/10.5489/cuai.3493

Published online December 14, 2015.

In the recent CUA Guideline on the management of CRPC, there was a missing word in the caption for Figure 1.

\section{Reference}

1. Saad F, Chi KN, Finelli A, et al. The 2015 CUA-CUOG Guideline for the management of castration-resistant prostate cancer (CRPC). Can Urol Assoc J 2015;9:90-6. http://dx.doi.org/10.5489/cuaj.2526

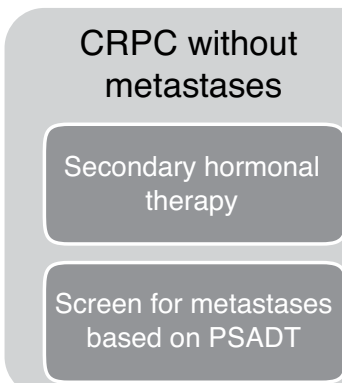

In the presence of bone metastases:

- Denosumab or Zoledronic Acid are recommended to reduce the risk of skeletal complications

- Palliative radiation therapy should be considered in patients with pain

Fig. 1. Management of castration-resistant prostate cancer (CRPC). PSADT: prostate-specific antigen doubling time. mCRPC: metastatic CRPC. ${ }^{*}$ Pending Health Canada approval in the chemo-naïve setting.

1. The optimal sequence of available options remains unknown.

2. Patients who have had little or no response to hormonal agents or who progress with minimal change in PSA or with significant visceral metastases should be considered for early chemotherapeutic options.

3. Radium-223 is not approved for patients with visceral metastases.

4. Whenever possible, clinical trials should remain the first choice in patients with CRPC. 


\section{Correction in author list}

Cite as: Can Urol Assoc J 2015;9(11-12):E925-6. http://dx.doi.org/10.5489/cuai.3494

Published online December 14, 2015.

In the recent article entitled, "Effects of desmopressin for the treatment of nocturnal polyuria in elderly women: Impact on related sleep quality," the correct author list is as follows: Jong-Hyeon Mun, MD; ${ }^{1}$ Sun-Ouck Kim, MD; ${ }^{2}$ Ho Song Yu, $M D ;{ }^{2}$ Ho Suck Chung, MD; ${ }^{2}$ Dongdeuk Kwon, MD ${ }^{2}$

Correct affiliations are as follows: ${ }^{1}$ Department of neurosurgery, Kwangju Christian Hospital, Gwangju, Korea; ${ }^{2}$ Department of Urology, Chonnam National University Medical School, Gwangju, Korea

\section{Correction in author contribution}

Cite as: Can Urol Assoc J 2015;9(11-12):E925-6. http://dx.doi.org/10.5489/cuai.3495

Published online December 14, 2015.

In an article entitled "Updated assessment of neobladder utilization and morbidity according to urinary diversion after radical cystectomy: A contemporary US-populationbased cohort,"1 the two first authors, Dr. Roghmann and Dr. Becker, equally contributed to the article.

\section{Reference}

1. Mun JH, Kim SO, Yu HS, et al. Effects of desmopressin for the treatment of nocturnal polyuria in elderly women: impact on related sleep quality. Can Urol Assoc J 2015;9:E770-4. http://dx.doi.org/10.5489/ cuaj.3097

\section{Reference}

1. Roghmann F, Becker A, Trinh QD, et al. Updated assessment of neobladder utilization and morbidity according to urinary diversion after radical cystectomy: A contemporary US-population-based cohort. Can Urol Assoc J 2013;7:e552-60. http://dx.doi.org/10.5489/cuaj.221

\section{Author addition}

Cite as: Can Urol Assoc J 2015;9(11-12):E925-6. http://dx.doi.org/10.5489/cuai.3496

Published online December 14, 2015.

In a recent case report, ${ }^{1}$ the following author should be listed as the last author: Muhammed Güzelsoy." ${ }^{11}$

\section{Reference}

1. Sambel M, Demirbas M, Yalcin 0, et al. Liposarcoma of the spermatic cord: A case report. Can Urol Assoc J 2015;9:E527-30. http://dx.doi.org/10.5489/cuaj.2827 